\title{
PENGARUH PENAMBAHAN MINYAK ZAITUN TERHADAP TEKANAN DARAH SISTOLIK PENDERITA HIPERTENSI YANG DIBERI JUS TOMAT
}

\author{
Ayu Ristia Daniati, Martha Irene Kartasurya*) \\ Program Studi Ilmu Gizi Fakultas Kedokteran Universitas Diponegoro \\ Jl.Dr.Sutomo No.18, Semarang, Telp (024) 8453708, Email : gizifk@ undip.ac.id
}

\begin{abstract}
Background : Untreated hypertension can lead to corronary heart disease, stroke, myocard infarc, heart failure, and renal disease. Tomato lycopene has antioxidant activity which can lower blood pressure. Olive oil increase lycopene absorption and it contains oleic acid.that can lower blood pressure.

Aim: The aim of this study was to analyze the effect of olive oil addition on tomato juice in systolic blood pressure of hypertension patients.

Methods : This study was a true experiment with pre - post test with control group design. The subjects were post menopausal women with systolic blood pressure of 140-159 $\mathrm{mmHg}$ that were randomly divided into two groups, 12 in treatment and 12 in control groups. The intervention was conducted in 7 days. The systolic blood pressure was measured by mercury Sphygmomanometer. Food intake was measured by 2x24-hours food recall and analyzed using nutrisurvey. Physical activity was measured with International Physical Activity Questionnaire (IPAQ). The statistical analysis was done by paired t-test, independent t-test, Wilcoxon, and Mann Whitney tests.

Result : The mean systolic blood pressure of the treatment group was $150.9 \pm 1.7 \mathrm{mmHg}$ before treatment and $136.4 \pm 4.5 \mathrm{mmHg}$ after treatment. Therefore the systolic blood pressure in treatment group were decreased by $14.5 \pm 4.7 \mathrm{mmHg}(p=0.002)$. The mean systolic blood pressure of the control group was $148.5 \pm 4.5 \mathrm{mmHg}$ before the treatment and $138.4 \pm 5.5 \mathrm{mmHg}$ after the treatment. Therefore the systolic blood pressure in control group were decreased by $10.1 \pm 2.3 \mathrm{mmHg}(p=0.0001)$. The treatment group had larger systolic blood pressure decrease compared to the control group $(p=0.007)$.

Conclusion : Additional $10 \mathrm{ml}$ olive oil $10 \mathrm{ml}$ on tomato juice for 7 days results in larger decrease of systolic blood pressure compared to tomato juice only.
\end{abstract}

Keyword : Lycopene; olive oil; tomato; hypertension; systolic blood pressure.

\begin{abstract}
ABSTRAK
Latar Belakang : Hipertensi merupakan faktor risiko terjadinya penyakit jantung koroner, stroke, infark miokardia, gagal jantung dan penyakit ginjal. Tomat mengandung likopen yang mempunyai aktivitas antioksidan sehingga dapat menurunkan tekanan darah. Minyak zaitun meningkatkan absorbsi likopen dari tomat dan mengandung asam oleat yang dapat menurunkan tekanan darah.

Tujuan: Menganalisis pengaruh penambahan minyak zaitun terhadap tekanan darah sistolik penderita hipertensi yang diberi jus tomat.

Metode : Jenis penelitian adalah true experiment dengan rancangan pre -post test with control group design. Subjek penelitian adalah wanita menopause dengan tekanan darah sistolik 140 - 159 mmHg yang dibagi menjadi dua kelompok, 12 pada kelompok perlakuan dan 12 pada kontrol. Intervensi dilakukan selama 7 hari. Tekanan darah sistolik diukur menggunakan Sphygmomanometer air raksa. Asupan makanan diukur menggunakan metode food recall $2 \times 24$ jam dan dianalisis menggunakan nutrisurvey. Aktivitas fisik dianalisis menggunakan International Physical Activity Questionnaire (IPAQ). Analisis statistik menggunakan uji paired t-test, Wilcoxon, independent $t$ test dan Mann Whitney.

Hasil : Ada penurunan tekanan darah sistolik pada kelompok perlakuan dari 150,9 $\pm 1,7$ mmHg menjadi 136,4 $\pm 4,5$

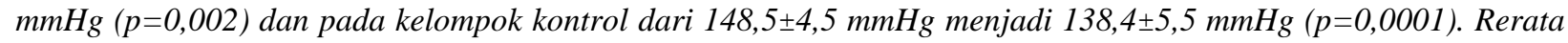
penurunan tekanan darah sistolik pada kelompok perlakuan 14,5 $\pm 4,7$ mmHg, lebih besar daripada kelompok kontrol 10,1 $+2,3 \mathrm{mmHg}(p=0,007)$
\end{abstract}

Kesimpulan : Jus tomat dengan minyak zaitun sebanyak 10ml selama 7 hari menurunkan tekanan darah sistolik lebih banyak daripada jus tomat saja.

Kata kunci : Likopen; minyak zaitun; tomat; tekanan darah; hipertensi.

\section{PENDAHULUAN}

Hipertensi merupakan suatu kondisi dimana aliran darah secara konsisten memiliki tekanan yang tinggi pada dinding arteri. Hipertensi merupakan faktor resiko terjadinya penyakit jantung koroner, stroke, infark miokardia, gagal jantung, dan penyakit ginjal. ${ }^{1}$ Pusat data dan informasi Kementerian Kesehatan RI menyebutkan baik tahun 2009 maupun 2010, hipertensi esensial menempati peringkat pertama penyebab rawat inap terhadap seluruh pasien di rumah sakit, selain itu hipertensi juga menjadi

\footnotetext{
${ }^{*}$ Penulis Penanggungjawab
} 
kasus baru terbanyak dari penyakit tidak menular yang terjadi pada pasien rawat jalan. ${ }^{2}$ Prevalensi hipertensi di Jawa Tengah tahun 2013 masih sebesar 26,4\%, dan di salah satu kabupaten di Jawa Tengah, yaitu Pati, hipertensi termasuk dalam daftar 10 kasus penyakit terbanyak yang terjadi di kabupaten tersebut. ${ }^{3,4}$

Prevalensi hipertensi meningkat dengan bertambahnya umur dan perempuan cenderung lebih tinggi daripada laki-laki. ${ }^{3}$ Tekanan darah sistolik wanita menopause lebih tinggi $21 \mathrm{mmHg}$ dan diastolik $8,5 \mathrm{mmHg}$ daripada wanita produktif. Menopause menyebabkan kadar estrogen dalam darah menurun, dimana sebelumnya estrogen berperan menjaga elastisitas sel endotel pembuluh darah. $^{5}$

Faktor-faktor yang mempengaruhi peningkatan tekanan darah adalah keturunan, usia, jenis kelamin, etnis, obesitas, kurangnya aktivitas fisik, stress, merokok, dan asupan. Pengaturan asupan makanan dan modifikasi diet merupakan salah satu cara untuk membantu menekan peningkatan tekanan darah. Pengaturan asupan makanan yang dianjurkan yaitu dengan peningkatan konsumsi sayur dan buah yang kaya akan mineral dan karotenoid. Salah satu jenis bahan makanan yang membantu menurunkan tekanan darah adalah tomat. ${ }^{6}$

Tomat memiliki manfaat menurunkan tekanan darah karena tomat mengandung likopen. Terdapat 4,6 mg likopen dalam 100 gram tomat segar. ${ }^{7}$ Likopen menurunkan tekanan darah melalui perannya sebagai antioksidan. Likopen mencegah radikal bebas menimbulkan stres oksidatif, kemudian memicu produksi nitrit oksida pada endotelium dan meningkatkan fungsi vaskuler, sehingga terjadi penurunan tekanan darah. ${ }^{8}$

Selama ini tomat sering dikonsumsi mentah dalam bentuk jus. Penelitian di Semarang tahun 2012 menyebutkan konsumsi jus tomat yang berasal dari 150 gram tomat mampu menurunkan tekanan darah sistolik sebesar 11,76 \pm 7,276 mmHg dan diastolik sebesar $8,82 \pm 3,321 \mathrm{mmHg} .{ }^{9}$ Penelitian lain tentang pengaruh likopen terhadap tekanan darah menyebutkan likopen hanya mampu menurunkan secara signifikan tekanan darah sistolik yaitu sebesar $11,5 \mathrm{mmHg}$ tetapi tidak mampu menurunkan tekanan diastolik. ${ }^{8}$

Pengaturan asupan makanan lain yang dapat menurunkan tekanan darah yaitu penggantian konsumsi minyak jenuh dengan minyak tidak jenuh rantai tunggal, salah satunya adalah minyak zaitun. Seratus mililiter minyak zaitun ekstra virgin mengandung 77,478 gram asam oleat yang dapat mencegah aktivasi endotelium dengan menghambat ekspresi molekul adhesi atau meningkatkan produksi NO. ${ }^{10}$ Konsumsi $60 \mathrm{ml}$ minyak zaitun terbukti dapat menurunkan tekanan darah sistolik pada lansia hipertensi sebesar 14 sampai $15 \mathrm{mmHg}$ dalam waktu empat minggu. ${ }^{11}$

Likopen yang terkandung dalam tomat akan mudah diabsorbsi bila dipanaskan dan dikonsumsi bersama dengan lemak. ${ }^{12}$ Kandungan likopen tomat yang diolah menjadi jus meningkat menjadi 9,5mg/100g. ${ }^{7}$ Penambahan minyak zaitun menjadikan likopen lebih mudah diabsorbsi. ${ }^{13}$ Perpaduan jus tomat dan minyak zaitun diharapkan dapat lebih signifikan menurunkan tekanan darah dibanding jus tomat tanpa penambahan minyak zaitun. ${ }^{11}$

Berdasarkan uraian di atas, maka peneliti ingin melakukan penelitian lebih lanjut tentang pengaruh penambahan minyak zaitun terhadap tekanan darah sistolik wanita postmenopause hipertensi yang diberi jus tomat.

\section{METODE PENELITIAN}

Penelitian ini merupakan penelitian true experimental dengan rancangan pre - post test with control group design yang menggunakan manusia sebagai subjek penelitian. Variabel bebas dalam penelitian adalah penambahan minyak zaitun $10 \mathrm{ml}$ dalam $350 \mathrm{ml}$ jus tomat, sedangkan variabel terikat adalah tekanan darah sistolik. Jus tomat dibuat dari $150 \mathrm{~g}$ tomat merah yang sudah diblansing selama 10 menit pada dalam $100 \mathrm{ml}$ air bersuhu $85-90^{\circ} \mathrm{C}$, kemudian ditambahkan $5 \mathrm{~g}$ gula pasir dan diblender. ${ }^{7}$ Selanjutnya, jus tomat untuk kelompok perlakuan ditambahkan $10 \mathrm{ml}$ minyak zaitun, sedangkan untuk kelompok kontrol jus tomat tidak ditambahkan minyak zaitun. Pemberian intervensi kelompok perlakuan dan kontrol dilakukan 1 kali sehari pada pagi hari selama 7 hari. Pelaksanaan penelitian telah mendapat persetujuan dari Komisi Etik Fakultas Kedokteran Universitas Diponegoro melalui terbitnya Ethical Clearance.

Subjek penelitian adalah perempuan usia 50-65 tahun di Kecamatan Wedarijaksa Kabupaten Pati. Kriteria inklusi dalam penelitian ini yaitu memiliki tekanan darah sistolik 140-159 mmHg, sudah mengalami menopause, memiliki IMT $23-27 \mathrm{~kg} / \mathrm{m}^{2}$, dapat diajak berkomunikasi, tidak merokok dan tidak mengkonsumsi alkohol, tidak sedang mengkonsumsi obat-obatan antihipertensi atau suplemen yang memberi efek hipotensi selama penelitian, tidak dalam keadaan sakit atau dalam perawatan dokter berkaitan dengan penyakit jantung koroner, penyakit ginjal, 
dan penyakit kronik lainnya, serta bersedia menjadi subjek penelitian dengan mengisi informed consent.

Perhitungan jumlah subjek penelitian menggunakan rumus perhitungan uji hipotesis rerata terhadap dua populasi dependen dengan sampel minimal 24 subjek, untuk antisipasi keluarnya sampel selama penelitian akibat drop out maka jumlah sampel ditambah $25 \%$ menjadi 30 orang. Metode pengambilan sampel yang digunakan adalah purposive sampling, yaitu semua subjek yang datang dan memenuhi kriteria pemilihan dimasukkan dalam penelitian hingga mencapai 30 orang. Pengelompokkan kelompok perlakuan dan kontrol dilakukan dengan membagi subjek secara acak, yang masing-masing kelompok terdiri dari 15 subjek. Selama proses penelitian 6 subjek mengalami drop out, sehingga masingmasing kelompok hanya terdiri dari 12 subjek.

Asupan makan selama intervensi kelompok perlakuan dan kontrol dicatat menggunakan metode food recall $2 \times 24$ jam, kemudian dianalisis menggunakan program nutrisurvey. Kecukupan asupan makanan (\%) dihitung berdasarkan kebutuhan subjek menurut golongan umur dan jenis kelamin pada AKG 2013. Aktivitas fisik dianalisis menggunakan kuesioner aktivitas fisik $I P A Q$ dengan penggolongan jumlah skor $<600$ dikategorikan rendah, untuk skor $600 \leq$ 2999 termasuk sedang, dan $\geq 3000$ dikategorikan berat. Status gizi ditentukan berdasarkan klasifikasi Indeks Massa Tubuh pada orang dewasa Asia yaitu status gizi overweight (23-24,9 $\left.\mathrm{kg} / \mathrm{m}^{2}\right)$ dan obesitas $\left(25-27 \mathrm{~kg} / \mathrm{m}^{2}\right)$. Tekanan darah sistolik diperiksa dua kali, yaitu satu hari sebelum intervensi dan satu hari setelah intervensi (pada hari ke-8). Tekanan darah sistolik diukur oleh seorang perawat yang sudah terlatih menggunakan Sphygmomanometer air raksa. Pengukuran tekanan darah dilakukan sebanyak 2 kali dengan selang waktu \pm 3 menit kemudian diambil rata-ratanya. Pengukuran dilakukan dalam posisi duduk bersandar, setelah beristirahat selama 5 menit. $^{8}$ Selama penelitian pengukuran tekanan darah dilakukan 1 kali sehari pada pagi hari sebelum pemberian jus tomat.

Uji Shapiro-Wilk digunakan untuk menguji kenormalan data. Analisis deskriptif digunakan untuk melihat gambaran karakteristik subjek. Perbedaan tekanan darah sistolik sebelum dan sesudah intervensi menggunakan Wilcoxon untuk data kelompok perlakuan dan uji paired $t$ test untuk data kelompok kontrol. Perbedaan pengaruh penambahan minyak zaitun dianalisis dengan menggunakan uji independent $t$-test.

\section{HASIL PENELITIAN}

Subjek penelitian Gambar 1.

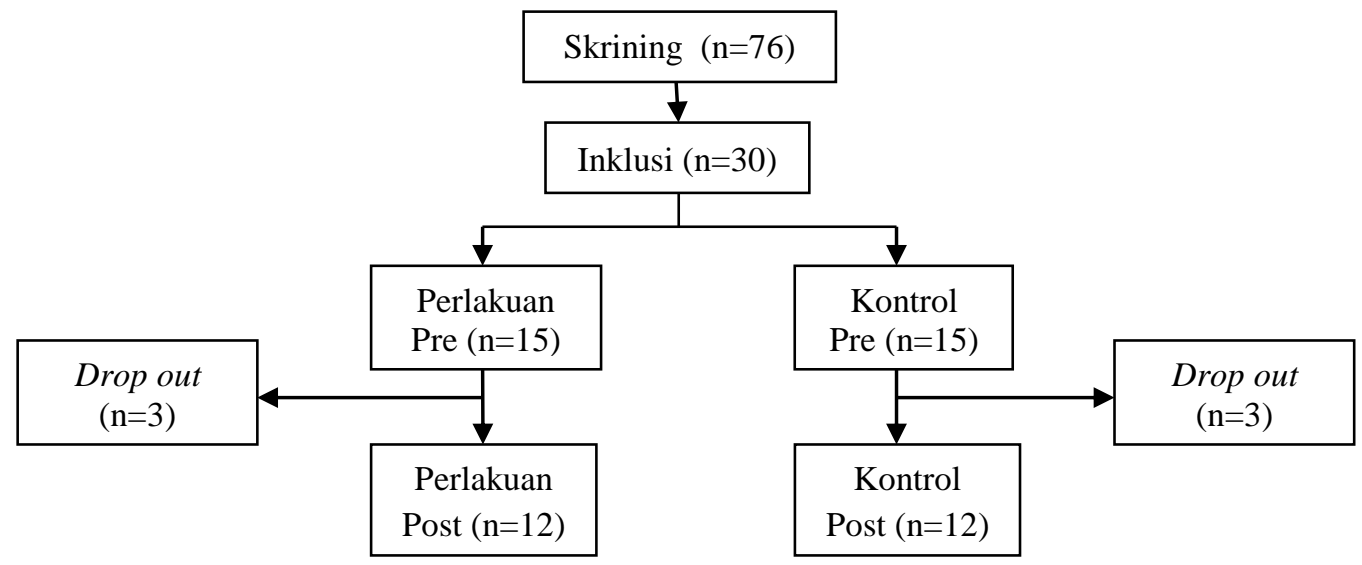

\section{Gambar 1. Subjek Penelitian}

Gambar 1 menunjukkan dari 76 subjek yang mengikuti skrining didapatkan 30 subjek yang memenuhi kriteria inklusi dan bersedia mengikuti penelitian. Tiga puluh subjek tersebut dibagi kedalam 2 kelompok yaitu perlakuan dan kontrol secara acak, masing-masing kelompok terdiri dari 15 subjek. Terjadi drop out selama proses penelitian sehingga pada akhir penelitian masing-masing kelompok hanya terdiri dari 12 subjek. Dua orang dari kelompok perlakuan mengalami diare dan 1 orang mengalami pusing, sedangkan pada kelompok kontrol 1 orang mengalami diare, 2 orang mengalami pusing. Subjek yang mengalami pusing di drop out karena subjek merasa tekanan darah mereka menjadi 
terlalu rendah dan tidak ingin melanjutkan penelitian.

\section{Karakteristik subjek}

Karakteristik subjek pada awal penelitian ditampilkan untuk mengetahui homogenitas variabel pada kedua kelompok dapat dilihat pada Tabel 1 .

Tabel 1. Karakteristik Subjek pada Awal Penelitian

\begin{tabular}{lccc}
\hline \multicolumn{1}{c}{ Variabel } & Perlakuan $(\mathrm{n}=12)$ & Kontrol $(\mathrm{n}=12)$ & \multirow{2}{*}{$\mathrm{p}$} \\
\cline { 2 - 3 } & Mean \pm SD & Mean \pm SD & \\
\hline Umur (tahun) & $57,9 \pm 3,9$ & $58,7 \pm 4,7$ & $0,678^{\mathrm{a}}$ \\
Indeks Masa Tubuh $\left(\mathrm{kg} / \mathrm{m}^{2}\right)$ & $25,6 \pm 0,9$ & $25,3 \pm 0,9$ & $0,478^{\mathrm{a}}$ \\
Aktivitas fisik (MET-menit/minggu) & $2617,3 \pm 805,3$ & $2087,3 \pm 1219,1$ & $0,223^{\mathrm{a}}$ \\
Tekanan Darah Sistolik Awal (mmHg) & $150,9 \pm 1,7$ & $148,5 \pm 4,5$ & $0,153^{\mathrm{b}}$ \\
\hline andependent t-test & & & \\
'Inann Whitney & & &
\end{tabular}

Tabel 1 menunjukkan tidak terdapat perbedaan umur, Indeks Masa Tubuh (IMT), aktivitas fisik, dan kolesterol total awal pada kedua kelompok sebelum dilakukan intervensi. Karakteristik subjek yang meliputi IMT dan aktivitas fisik dirinci pada Tabel 2.

Tabel 2. Karakteristik Subjek

\begin{tabular}{lccccc}
\hline \multirow{2}{*}{ Variabel } & \multicolumn{2}{c}{ Perlakuan $(\mathrm{n}=12)$} & \multicolumn{2}{c}{ Kontrol $(\mathrm{n}=12)$} & $\mathrm{p}$ \\
\cline { 2 - 5 } & $\mathrm{n}$ & $\%$ & $\mathrm{n}$ & $\%$ & \multirow{2}{*}{$1.000^{\mathrm{e}}$} \\
\hline Indeks Masa Tubuh & 2 & 16,7 & 3 & 25,0 & \\
Overweight & 10 & 83,3 & 9 & 75,0 & \multirow{2}{*}{$1.000^{\mathrm{e}}$} \\
Obesitas & 5 & 41,7 & 7 & 58,3 & \\
\hline Aktivitas fisik & 7 & 58,3 & 5 & 41,7 & \\
Sedang & & & & & \\
Berat & & & & & \\
\hline
\end{tabular}

${ }^{\mathrm{e}}$ Fisher's Exact Test

Tabel 2 menunjukkan tidak ada beda kategori aktifitas fisik maupun IMT antara kedua kelompok, sehingga variabel kategori aktifitas fisik dan IMT bukan menjadi variabel perancu.

\section{Asupan Zat Gizi Selama Intervensi}

Tingkat kecukupan kebutuhan energi, protein, lemak jenuh, serat, natrium, kalium, magnesium, dan kalsium selama intervensi pada kedua kelompok dapat dilihat pada Tabel 3.

Tabel 3. Tingkat Kecukupan Kebutuhan Zat Gizi Selama Intervensi

\begin{tabular}{lccc}
\hline \multicolumn{1}{c}{ Variabel } & $\begin{array}{c}\text { Perlakuan } \\
(\mathrm{n}=12)\end{array}$ & $\begin{array}{c}\text { Kontrol } \\
(\mathrm{n}=12)\end{array}$ & \\
\cline { 2 - 3 } & Mean $\pm \mathrm{SD}$ & Mean $\pm \mathrm{SD}$ & $0,425^{\mathrm{a}}$ \\
\hline Tingkat Kecukupan energi(\%) & $88,7 \pm 5,1$ & $90,2 \pm 3,9$ & $0,662^{\mathrm{a}}$ \\
Tingkat Kecukupan protein(\%) & $88,3 \pm 12,4$ & $86,3 \pm 9,8$ & $0,975^{\mathrm{a}}$ \\
Tingkat Kecukupan lemak jenuh(\%) & $107,0 \pm 30,3$ & $107,3 \pm 22,0$ & $0,069^{\mathrm{a}}$ \\
Tingkat Kecukupan serat(\%) & $33,9 \pm 5,2$ & $39,7 \pm 9,0$ & $0,276^{\mathrm{a}}$ \\
Tingkat Kecukupan natrium(\%) & $137,7 \pm 48,2$ & $118,7 \pm 33,4$ & $0,237^{\mathrm{a}}$ \\
Tingkat Kecukupan kalium(\%) & $33,5 \pm 5,2$ & $36,0 \pm 4,8$ & $0,725^{\mathrm{a}}$ \\
Tingkat Kecukupan magnesium(\%) & $75,3 \pm 14,5$ & $77,3 \pm 12,6$ & $0,817^{\mathrm{b}}$ \\
Tingkat Kecukupan kalsium(\%) & $21,2 \pm 4,4$ & $22,7 \pm 9,2$ &
\end{tabular}

${ }^{\mathrm{a} U j i}$ beda Independent T-test

${ }^{b}$ Uji Mann Whitney

Tabel 3 menunjukkan tingkat kecukupan kebutuhan zat gizi subjek menurut golongan umur dan jenis kelamin pada AKG 2013. Berdasarkan uji beda, tidak terdapat perbedaan bermakna 
tingkat kecukupan kebutuhan energi, protein, lemak jenuh, serat, natrium, kalium, magnesium, dan kalsium pada kedua kelompok, sehingga tingkat kecukupan kebutuhan zat gizi bukan merupakan variabel perancu.

\section{Tingkat Kepatuhan Konsumsi Jus}

Tingkat kepatuhan konsumsi jus tomat selama intervensi pada kedua kelompok dapat dilihat pada Tabel 4.

Tabel 4. Tingkat Kepatuhan Konsumsi Jus Tomat

\begin{tabular}{cccc}
\hline \multirow{2}{*}{ Variabel } & $\begin{array}{c}\text { Perlakuan } \\
(\mathrm{n}=12)\end{array}$ & $\begin{array}{c}\text { Kontrol } \\
(\mathrm{n}=12)\end{array}$ & $\mathrm{p}$ \\
\cline { 2 - 3 } & Mean \pm SD & Mean \pm SD & \\
\hline Tingkat kepatuhan $(\%)$ & $92,3 \pm 9,5$ & $84,2 \pm 12,4$ & $0,090^{\mathrm{b}}$ \\
\hline${ }^{\mathrm{b}}$ Uji Mann Whitney & & &
\end{tabular}

Tabel 4 menunjukkan tidak ada perbedaan tingkat kepatuhan konsumsi jus antara kedua kelompok. Tingkat asupan kelompok perlakuan selama penelitian adalah $92,3 \%$, sedangkan tingkat asupan kelompok kontrol adalah 84,2\%.
Pengaruh Penambahan Minyak Zaitun dalam Jus Tomat terhadap Tekanan Darah Sistolik

Perbedaan tekanan darah sistolik sebelum dan setelah intervensi disajikan untuk melihat perubahan rerata tekanan darah sistolik masingmasing kelompok dan antara kedua kelompok sebelum dan setelah mengkonsumsi jus tomat dengan penambahan minyak zaitun dan jus tomat saja selama 7 hari.

Tabel 5. Perbedaan Tekanan Darah Sistolik Sebelum dan Setelah Intervensi

\begin{tabular}{lccc}
\hline \multicolumn{1}{c}{$\begin{array}{c}\text { Tekanan Darah Sistolik } \\
\text { (mmHg) }\end{array}$} & $\begin{array}{c}\text { Perlakuan } \\
\mathrm{n}=12\end{array}$ & $\begin{array}{c}\text { Kontrol } \\
\mathrm{n}=12\end{array}$ & $\mathrm{p}$ \\
\cline { 2 - 3 } & $\mathrm{Mean} \pm \mathrm{SD}$ & Mean $\pm \mathrm{SD}$ & \\
\hline Sebelum & $150,9 \pm 1,7$ & $148,5 \pm 4,5$ & $0,153^{\mathrm{b}}$ \\
Setelah & $136,4 \pm 4,5$ & $138,4 \pm 5,5$ & $0,342^{\mathrm{a}}$ \\
$\Delta$ (setelah-sebelum) & $14,5 \pm 4,7$ & $10,1 \pm 2,3$ & $0,007^{\mathrm{b}}$ \\
Persentase penurunan & $9,6 \%$ & $6,8 \%$ & \\
$\mathrm{p}$ & $0,002^{\mathrm{c}}$ & $0,0001^{\mathrm{d}}$ & \\
\hline \multicolumn{2}{c}{${ }^{\mathrm{a}}$ Independent t-test ${ }^{\mathrm{b}}$ Mann Whitney ${ }^{\mathrm{c}}$ Uji beda Wilcoxon ${ }^{\mathrm{d}}$ Paired t-test }
\end{tabular}

Hasil uji beda menunjukkan adanya perbedaan bermakna tekanan darah sistolik sebelum dan sesudah intervensi pada kedua kelompok. Terdapat perbedaan bermakna penurunan tekanan darah sistolik antara kedua kelompok $(\mathrm{p}=0,007)$. Rerata penurunan tekanan darah sistolik pada kelompok perlakuan lebih besar daripada rerata penurunan tekanan darah sistolik pada kelompok kontrol. Pada kelompok perlakuan rerata penurunan tekanan darah sebesar $14,5 \pm 4,7 \mathrm{mmHg}$ dan kelompok kontrol penuruan sebesar 10,1 $\pm 2,3 \mathrm{mmHg}$.

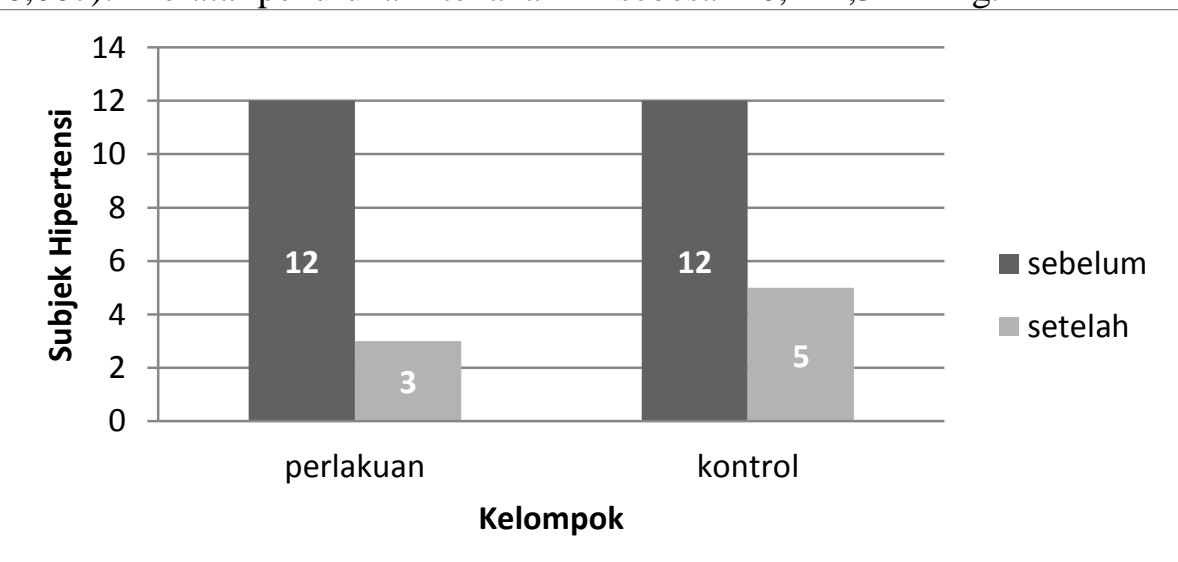

Grafik 1. Presentase Tekanan Darah Sistolik yang Masih Diatas 140 mmHg (Hipertensi) 
Grafik 1 menunjukkan bahwa semua subjek pada kedua kelompok sebelum intervensi mengalami hipertensi. Setelah intervensi selama 7 hari, tekanan darah sistolik 8 dari 12 subjek $(75 \%)$ pada kelompok perlakuan dan 7 dari 12 subjek (58\%) pada kelompok kontrol menjadi normal.

\section{PEMBAHASAN}

Tidak terdapat perbedaan umur, status gizi, aktivitas fisik, dan tekanan darah sistolik sebelum intervensi antara kelompok kontrol dan perlakuan, sehingga umur, status gizi, dan aktifitas fisik bukan menjadi variabel perancu. Karakteristik subjek dalam penelitian ini adalah wanita menopause berusia $50-65$ tahun. Pada kondisi menopause terjadi penurunan kadar estrogen dalam darah, dimana sebelumnya estrogen berperan menjaga elastisitas sel endotel pembuluh darah. ${ }^{5}$ Beberapa penelitian menunjukkan, semakin tua umur seseorang maka semakin tinggi tekanan darahnya, hal ini disebabkan karena seiring dengan pertambahan usia lumen pembuluh darah menyempit dan elastisitas vaskuler menurun. ${ }^{15}$ Menurunnya elastisitas vaskuler ini menyebabkan kakunya dinding arteri yang dapat memicu peningkatan tekanan darah. ${ }^{16}$

Penurunan tekanan darah pada kelompok perlakuan yang terdiri dari $83 \%$ subjek obesitas menunjukkan penurunan tekanan darah yang lebih besar dari kelompok kontrol yang terdiri dari $75 \%$ subjek obesitas. Subjek dengan status gizi obesitas beresiko menderita hipertensi sebesar 4,02 kali dibanding dengan orang yang tidak obesitas, sehingga penting bagi penderita hipertensi untuk menjaga status gizinya tetap dalam kategori normal. ${ }^{17}$

Kelompok perlakuan yang terdiri dari $58,3 \%$ dengan aktifitas fisik berat menunjukkan penurunan tekanan darah yang lebih besar daripada kelompok kontrol yang terdiri dari 58,3\% subjek dengan aktifitas fisik sedang. Aktifitas fisik yang baik untuk menurunkan tekanan darah adalah aktivitas fisik yang mencakup kegiatan berintensitas ringan-sedang seperti berjalan cepat, bersepeda santai atau senam kesehatan dibanding tingkat berat. Aktifitas fisik berat seperti angkat beban justru dapat meningkatkan tekanan darah. ${ }^{18,19}$ Hasil dari penelitian ini menunjukkan bahwa tidak terdapat perbedaan usia, status gizi, dan aktifitas fisik pada kedua kelompok, sehingga variabel-variabel tersebut bukan merupakan variabel perancu.

Tingkat kecukupan energi pada kelompok kontrol tergolong cukup (90-119\%) dan kelompok perlakuan kurang $(<90 \%)$. Tingkat kecukupan protein pada kedua kelompok tergolong kurang $(<90 \%)$. Tingkat kecukupan serat, kalium, dan kalsium pada kedua kelompok tergolong kurang $(<77 \%)$. Tingkat kecukupan magnesium pada kelompok perlakuan tergolong kurang $(<77 \%)$, sedangkan pada kelompok kontrol tergolong cukup $(\geq 77 \%)$. Tingkat kecukupan natrium pada kedua kelompok diatas $100 \% .^{20}$ Hasil dari penelitian ini menunjukkan bahwa tidak terdapat perbedaan tingkat kecukupan asupan energi, protein, lemak jenuh, serat, natrium, kalium, magnesium, dan kalsium pada kedua kelompok, sehingga variabel-variabel tersebut bukan merupakan variabel perancu.

Kepatuhan konsumsi jus pada kelompok perlakuan sebesar 92,3\% dan kelompok kontrol sebesar $84,22 \%$. Hasil uji beda menunjukkan bahwa tidak ada beda kepatuhan asupan antara kelompok perlakuan dan kontrol. Ketidaksukaan subjek terhadap rasa jus tomat yang diberikan menyebabkan tingkat asupan pada kedua kelompok tidak mencapai $100 \%$.

Terjadi penurunan tekanan darah sistolik pada kelompok kontrol karena pada kelompok kontrol diberikan jus tomat. Penelitian di Semarang tahun 2012 menyebutkan konsumsi jus tomat yang berasal dari 150 gram tomat mampu menurunkan tekanan darah sistolik sebesar 11,76 \pm 7.276 mmHg. ${ }^{9}$ Tomat mengandung sejumlah karotenoid seperti likopen, zeaxanthin, betakaroten, dan lutein. ${ }^{21}$ Komposisi karotenoid dalam ekstrak tomat adalah sebagai berikut, $86 \%$ alltrans-lycopene, 6\% 5-cis-lycopene, 2\% 9-cislycopene, dan 2\% 13-cis-lycopene, dan 4\% karotenoid lainnya. ${ }^{22}$ Komposisi tersebut menunjukkan bahwa likopenlah yang paling banyak terdapat dalam tomat. 


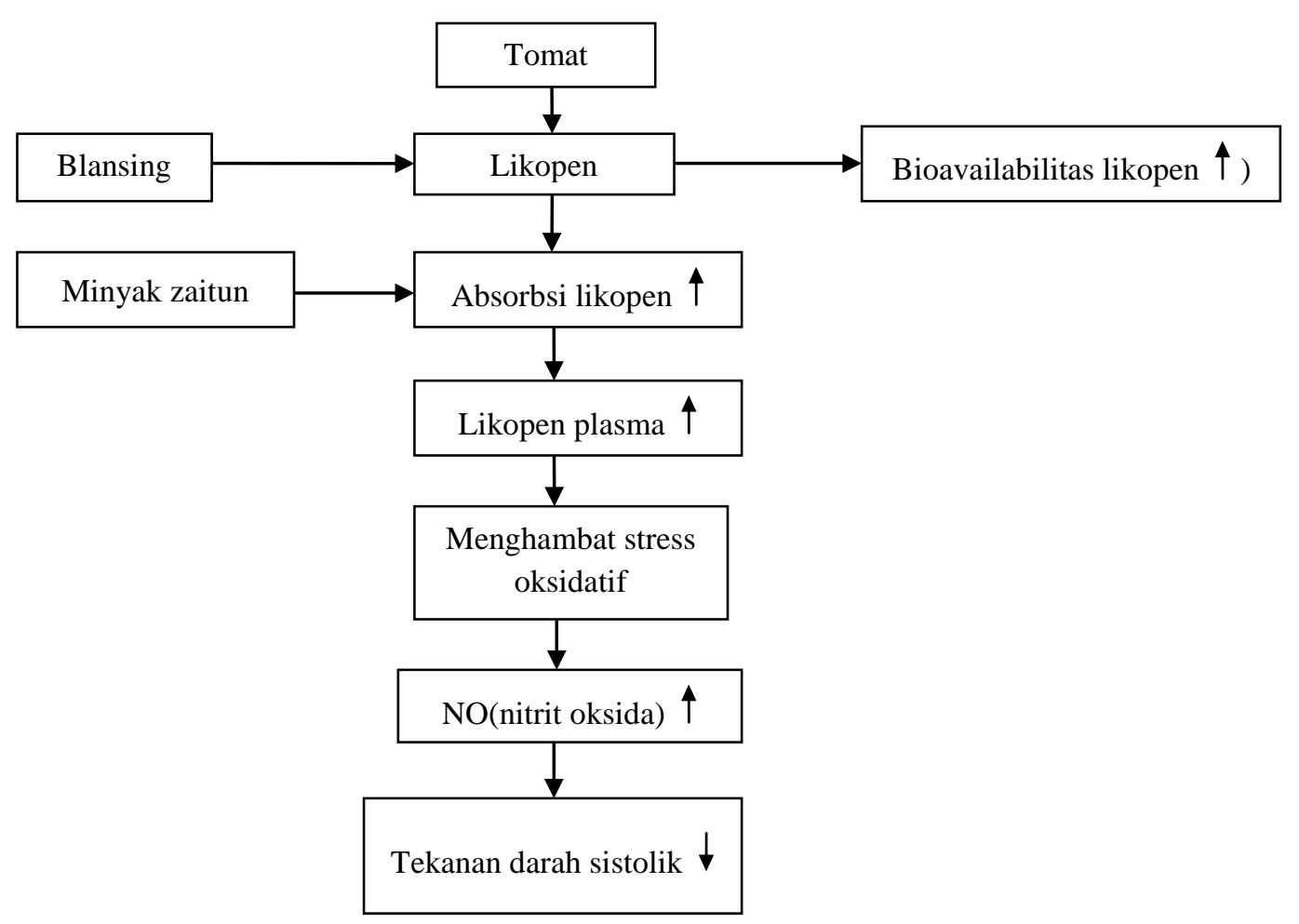

Gambar 2. Mekanisme Likopen Menurunkan Tekanan Darah

Likopen merupakan antioksidan dengan kemampuan meredam oksigen tunggal dua kali lebih baik daripada beta-karoten dan sepuluh kali lebih baik daripada alfa-tokoferol. Likopen menurunkan tekanan darah melalui perannya sebagai antioksidan, seperti yang terlihat pada gambar 2. Likopen mencegah radikal bebas yaitu ROS (reactive oxigen spesies) menimbulkan stres oksidatif, kemudian memicu produksi nitrit oksida pada endotelium dan meningkatkan fungsi vaskuler, sehingga terjadi penurunan tekanan darah. $^{8,23}$ Kalium dalam tomat juga berpengaruh terhadap penurunan tekanan darah. Terdapat 222 mg kalium dalam $100 \mathrm{~g}$ tomat segar. Penambahan asupan kalium minimal $60 \mathrm{mmol}(2340 \mathrm{mg}$ ) per hari dapat menurunkan tekanan darah sistolik 4,4 $\mathrm{mmHg}$ dan diastolik 2,5 $\mathrm{mmHg}$ pada subjek hipertensi. ${ }^{724}$ Diet tinggi kalium akan mempengaruhi vasodilatasi endotelium. Diet tinggi kalium dapat mencegah retensi natrium, sehingga menambah produksi nitrit oksida, sebuah vasodilator arteri yang ada pada sel endotel. ${ }^{25}$

Penambahan minyak zaitun dalam jus tomat selama 7 hari dapat menambah besar penurunan tekanan darah sistolik. Terbukti dengan penurunan tekanan darah sistolik yang terjadi pada kelompok kontrol terjadi tidak sebesar kelompok perlakuan. Hasil uji statistik menunjukkan ada perbedaan bermakna rerata penurunan tekanan darah sistolik antar kedua kelompok. Pada kelompok perlakuan, terjadi penurunan tekanan darah sistolik sebesar $14,5 \pm 4,7 \mathrm{mmHg}(6,8 \%)$, sedangkan pada kelompok kontrol hanya terjadi penurunan tekanan darah sistolik sebesar 10,1 $\pm 2,3$ $\mathrm{mmHg}(9,6 \%)$.

Penurunan tekanan darah sistolik pada kelompok perlakuan lebih besar dibandingkan dengan kelompok kontrol karena pada kelompok perlakuan diberikan tambahan minyak zaitun. Minyak zaitun diketahui dapat menurunkan tekanan darah karena pada minyak zaitun mengandung asam lemak tak jenuh tunggal yaitu asam oleat. Asam oleat pada minyak zaitun dapat meningkatkan produksi NO yang kemudian dapat menurunkan tekanan darah. ${ }^{26}$ Penurunan tekanan darah juga dikaitkan dengan perubahan komposisi membran sel endotelium setelah mengkonsumsi asam oleat, yang kemudian mempengaruhi fungsinya. ${ }^{27}$ Konsumsi minyak zaitun dan pola diit mediteranian berhubungan terbalik dengan tekanan darah. Konsumsi $60 \mathrm{ml}$ minyak zaitun terbukti dapat menurunkan tekanan darah sistolik pada lansia hipertensi sebesar 14 sampai $15 \mathrm{mmHg}$ dalam waktu empat minggu. ${ }^{11}$

Penambahan minyak zaitun pada jus tomat menjadikan likopen lebih mudah diabsorbsi karena memfasilitasi likopen menuju fase lipofilik, sehingga lebih bioavailabel. ${ }^{28}$ Absorbsi likopen yang lebih optimal inilah yang menjadikan penurunan tekanan darah kelompok perlakuan 
lebih besar. Selain itu, penelitian sebelumnya menyebutkan bahwa konsumsi tomat yang diolah menggunakan minyak zaitun dapat meningkatkan likopen dalam plasma lebih tinggi dibandingkan tomat yang diolah tanpa minyak zaitun. ${ }^{13}$ Likopen plasma merupakan antioksidan dalam plasma dan tekanan darah berhubungan negatif dengan plasma antioksidan Jika terjadi hipertensi maka antioksidan plasma akan turun dan ini menandakan stres oksidasi meningkat, tapi sebaliknya jika antioksidan plasma meningkat dan menandakan stres oksidasi menurun, maka tekanan darah akan turun. $^{23,29}$

\section{SIMPULAN}

Jus tomat dengan minyak zaitun sebanyak $10 \mathrm{ml}$ selama 7 hari menurunkan tekanan darah sistolik lebih banyak daripada jus tomat saja.

\section{SARAN}

1. Penderita hipertensi dapat mengkonsumsi jus tomat dengan penambahan minyak zaitun sebagai alternatif minuman untuk menurunkan tekanan darah.

2. Pada penderita hipertensi sistolik grade I perlu dilakukan peningkatan asupan antioksidan salah satunya likopen.

\section{DAFTAR PUSTAKA}

1. Pujol TJ, Tucker JE, Barner JT. Diseases of the Cardiovascular System . In: Nelms M, Sucher KP, Lacey K, Roth SL, editors. Nutrition Therapy and Pathophysiology. 2nd ed. Wadsworth Cengage Learning; 2011. p.288-97.

2. Gambaran Penyakit Tidak Menular di Rumah Sakit di Indonesia Tahun 2009 dan 2010. Pusat Data dan Informasi Kementerian Kesehatan RI. 2010.

3. Riset Kesehatan Dasar 2013. Departemen Kesehatan Republik Indonesia. Desember 2013.

4. Prevalensi 10 Kejadian Penyakit Tertinggi di Kabupaten Pati Tahun 2013. Dinas Kesehatan Kabupaten Pati. 2013.

5. Nugraha CW. Pengaruh Menopause terhadap Tekanan Darah [skripsi]. Bandung: Fakultas Kedokteran Universitas Kristen Maranatha. 2010.

6. Bhowmik D, Kumar KPS, Paswan S, Srivastava S. Tomato-A natural medicine and Its Health Benefit. Journal of Pharmacognosy and Phytochemistry 2012; 1(1): 33-43.

7. Kailaku SI, Dewantari KT, Sunarmani. Potensi Likopen dalam Tomat untuk Kesehatan. Buletin Teknologi Pascapanen
Pertanian Vol 3, Balai Besar Penelitian dan Pengembangan Pascapanen Pertanian. 2007.

8. Xinli L, Jiuhong X. Lycopene Supplement and Blood Pressure : An Updated MetaAnalysis of Intervention Trials. Nutrients 2013; 5: 3696-712.

9. Lestari AP. Pengaruh Pemberian Jus Tomat (Lycopersicum commune) terhadap Tekanan Darah Wanita Postmenopause Hipertensif. Program Studi Ilmu Gizi Fakultas Kedokteran Universitas Diponegoro, Semarang. 2012.

10. Nugraheni K. Pengaruh Pemberian Minyak Zaitun Ekstra Virgin terhadap Profil Lipid Serum Tikus Putih Strain Sprague Dawley Hiperkolesterolemia. Semarang: Program Studi Ilmu Gizi Fakultas Kedokteran Universitas Diponegoro. 2012.

11. Perona JS, Canizares J, Montero E, SanchezDominguez JM, Catala A, Ruiz-Gutierrez V. Virgin olive oil reduces blood pressure in hypertensive elderly subjects. Clinical Nutrition 2004; 23: 1113-21.

12. Ahuja KDK, Pittaway JK, Ball MJ. Effects of Olive Oil and Tomato Lycopene Combination on Serum Lycopene, Lipid Profile, and Lipid Oxidation. Nutrition 2006; 22: 259-65.

13. Fielding JM, Rowley KG, Cooper P, O’Dea $\mathrm{K}$. Increase in Plasma Lycopene Concentration after Consumption ot Tomatoes Cooked with Olive Oil. Asia Pac J Clin Nutr 2005; 14 (2): 131-6.

14. Pedoman Teknis Penemuan dan Tatalaksana Penyakit Hipertensi. Direktorat Pengendalian Penyakit Tidak Menular Direktorat Jenderal PP \& PL Departemen Kesehatan RI. 2006.

15. Rahajeng E, Tuminah S. Prevalensi Hipertensi dan Determinannya di Indonesia. pusat Penelitian Biomedis dan Farmasi Badan Penelitian Kesehatan, Departemen Kesehatan RI, Jakarta. Desember 2009.

16. Logan A. Hypertension in Aging Patients. Expert Rev. Cardiovasc. Ther. 2011;9(1):113120.

17. Sugiharto A. Faktor-Faktor Risiko Hipertensi Grade II pada Masayarakat. Program Studi Magister Epidemiologi Program Pasca Sarjana Universitas Diponegoro, Semarang. 2007.

18. Assessing and Managing Raised Blood Pressure in Adults. Heart Foundation Guide to Management of Hypertension. 2008.

19. Monteiro MDF, Filho DCS. Physical Exercise and Blood Pressure Control. Rev Bras Med Esporte. 2004;10(16):517-9. 
20. Ahuja KDK, Pittaway JK, Ball MJ. Effects of Olive Oil and Tomato Lycopene Combination on Serum Lycopene, Lipid Profile, and Lipid Oxidation. Nutrition 2006; 22: 259-65.

21. Briawan D, Adrianto Y, Ernawati D, Syamsir E, Aries M. Konsumsi Pangan, Bioavailibilitas Zat Besi dan Status Anemia Siswi di Kabupaten Bogor. Bogor: Prosiding Seminar Hasil-Hasil Penelitian IPB. 2012.

22. Ganesan M, Rajesh M, Solairaj $P$, Senthilkumar T. Tomato as A Pioneer in Health Management. IJPCBS 2012, 2(3), 21017

23. Beg M, Sharma V, Akhtar N, Gupta A, Mohd J. Review Article: Role of Antioxidants in Hypertension. Journal Indian Academy of Clinical Medicine 2011; 12 (2): 122-27.

24. Adrogue HJ, Madias NE. Sodium and Potassium in the Pathogenesis of Hypertension. N Engl J Med 2007; 356 (19): 1966-78.

25. Houston MC. The Importance of Potasssium in Managing Hypertension. Curr Hypertens Rep. 2011.

26. Covas MI. Olive Oil and The Cardiovascular System. Pharmacological Research 2007; 55: 175-86.

27. Perona JS, Cabello-Moruno R, Ruiz-Gutierrez V. The Role of Virgin Olive Oil Components in The Modulation of Endothelial Function. Journal of Nutritional Biochemistry 2006; 17: 429-45.

28. Appel LJ. Diet and Blood Pressure. In : Ross AC, Caballero B, Cousins RJ, Tucker KL, Ziegler TR, editors. Modern Nutrition: in Health and Disease. 11th edition. Philadelphia: Wolters Kluwer|Lippincott Williams \& Wilkins; 2014. p:875-85.

29. Rodrigo R, Prat H, Passalacqua W, Araya J, Guichard C, Bachler JP. Relationship between Oxidative Stress and Essential Hypertension. Hypertens Res 2007; 30(12): 1159-67. 